\title{
Identification of a single cytosine base insertion mutation at Arg-597 of the $\beta$ subunit of the human epithelial sodium channel in a family with Liddle's disease
}

Toshihiko Inoue, Yasuhiro Okauchi, Yasuyuki Matsuzaki, Kazuko Kuwajima, Hideki Kondo, Noriaki Horiuchi, Katsuyuki Nakao, Masayasu Iwata, Yutaka Yokogoshi ${ }^{1}$, Yasumi Shintani ${ }^{1}$, Hiroshi Bando ${ }^{1}$ and Shiro Saito $^{1}$

Department of Internal Medicine, Okawa General Hospital, Kagawa, Japan and ${ }^{1}$ First Department of Internal Medicine, School of Medicine, University of Tokushima, Tokushima, Japan

(Correspondence should be addressed to T Inoue, Department of Internal Medicine, Okawa General Hospital, 387 Sangawa-cho, Kagawa Prefecture 769-2321, Japan)

\begin{abstract}
We describe a family with Liddle's disease caused by a novel mutation of the $\beta$ subunit of the human epithelial sodium channel (ENaC). A 15-year-old Japanese female was referred to our outclinic because of hypertension. The physical examination showed no abnormal findings except mild hypertension, but the laboratory data revealed low levels of plasma renin activity, plasma aldosterone and serum potassium. A comprehensive analysis of steroid hormones showed only high levels of urinary free cortisol and 17-hydroxycorticosteroids. During loading tests, blood pressure and serum potassium responded well to triamterene and slightly to spironolactone, but did not respond to dexamethasone. In addition, the normal ratio of tetrahydrocortisol plus $5 \alpha$-tetrahydrocortisol to tetrahydrocortisone in a $24 \mathrm{~h}$ urinary excretion test strongly suggested a diagnosis of Liddle's disease rather than apparent mineralocorticoid excess syndrome. DNA sequence analysis of members of this family revealed a single cytosine base insertion at Arg-597 of the $\beta$ human $\mathrm{ENaC}$ in the proband and her mother, leading to a loss of the last 34 amino acids from the normally encoded protein as the result of a frameshift. We conclude that a de novo cytosine insertion into the final exon of the $\mathrm{C}$-terminus of the $\beta$ human $\mathrm{ENaC}$ is responsible for Liddle's disease in this Japanese family.
\end{abstract}

European Journal of Endocrinology 138 691-697

\section{Introduction}

Liddle's syndrome is a rare disease inherited as an autosomal dominant trait (1-5). Patients with Liddle's syndrome are characterized by increased plasma volume caused by excessive salt and water reabsorption in the distal nephron, resulting in low levels of plasma renin activity, plasma aldosterone and serum potassium, and metabolic alkalosis. These abnormalities can be corrected by dietary salt restriction and administration of antagonists of the epithelial sodium channel $(\mathrm{ENaC})$, e.g. amiloride and triamterene. The pathophysiology has recently been confirmed as abnormal subunits of the ENaC which cause excessive salt absorption in the distal nephron (6-9). The ENaC plays a major role in fluid absorption in the kidney, lung and colon and also constitutes the rate-limiting step for sodium absorption $(8,10-12)$; it is a multimer consisting of $\alpha, \beta$ and $\gamma$ subunits (2, 7-9). These three subunits have been cloned in rats and humans $(6$, 10, 13). Canessa et al. (10) reported the structure and function of the $\beta$ subunit of rat $\mathrm{ENaC}$, and recognized them as important candidate genes for causing Liddle's syndrome. Subsequently, McDonald et al. (13) cloned human $\beta$ and $\gamma$ subunits, and demonstrated that $\beta$ human $\mathrm{ENaC}$ (hENaC) DNA had an open reading frame of 1920 nucleotides encoding a protein of 640 amino acids with a predicted size of $73 \mathrm{kDa}$. Clinical investigators have recently demonstrated that some mutations of the cytoplasmic C-termimus of the $\beta$ or $\gamma$ hENaC cause truncation of a part of the C-terminus, leading to increased activity of the ENaC (14-18). The activity of the $\alpha \mathrm{hENaC}$ has been shown to be greatly augmented by the co-expression of abnormal $\beta$ or $\gamma$ subunits $(6,13-18)$. These results indicate that the cytoplasmic C-terminus of the $\beta$ or $\gamma$ hENaC is involved in the normal negative regulation of channel activity and that these subunits may act independently $(2-5,15)$. Since the pathogenesis of Liddle's syndrome has gradually been clarified by recent clinical and genomic analysis, some authors have adopted the term 'Liddle's disease' rather than 'Liddle's syndrome' $(6,17)$. Therefore, in this report we use 'Liddle's disease' to refer to this congenital disorder. We describe a kindred with Liddle's disease whose proband showed laboratory data similar to those for apparent mineralocorticoid excess (AME) syndrome, but whose condition was found to be caused by an insertion mutation of the C-terminus of the $\beta$ hENaC. In 
addition, genetic mutations of the $\beta$ or $\gamma \mathrm{hENaC}$ are reviewed in the eight families with Liddle's disease reported in the literature to date.

\section{Materials and methods}

\section{Case 1}

A 15-year-old Japanese female was referred to our hospital for further investigation of hypertension in
September 1994. Her weight was $63 \mathrm{~kg}$, height $162 \mathrm{~cm}$, blood pressure $154 / 92 \mathrm{mmHg}$, and pulse rate $66 / \mathrm{min}$. Neither goitre nor heart murmur was found. Her ocular fundus was normal and there was no left ventricular hypertrophy on electrocardiography or ultrasonic cardiography. She had normal genital organs and was not ingesting licorice. The laboratory data on admission are shown in Table 1. Urinalysis, complete blood counts, liver function tests and serological tests were all normal. Serum potassium was low $(3.3 \mathrm{mEq} / \mathrm{l})$. An arterial blood

Table 1 Laboratory data of the proband with Liddle's disease on admission.

\begin{tabular}{|c|c|}
\hline $\begin{array}{l}\text { Urinalysis } \\
\text { Complete blood counts } \\
\text { Liver function tests and serological tests }\end{array}$ & $\begin{array}{l}\text { Within normal limits } \\
\text { Within normal limits } \\
\text { Within normal limits }\end{array}$ \\
\hline $\begin{array}{l}\text { Serum electrolytes } \\
\text { Sodium } \\
\text { Potassium } \\
\text { Chloride } \\
\text { Calcium } \\
\text { Phosphorus }\end{array}$ & $\begin{array}{l}146 \mathrm{mEq} / \mathrm{l}(135-147) \\
3.3 \mathrm{mEq} / \mathrm{l}(3.6-5.0) \\
105 \mathrm{mEq} / \mathrm{l}(98-108) \\
9.4 \mathrm{mg} / \mathrm{dl}(8.4-10.2) \\
4.1 \mathrm{mg} / \mathrm{dl}(2.5-4.5)\end{array}$ \\
\hline $\begin{array}{l}\text { Arterial blood gas analysis } \\
\mathrm{pH} \\
\mathrm{PaCO}_{2} \\
\mathrm{PaO}_{2} \\
\mathrm{HCO}_{3}^{-} \\
\mathrm{BE} \\
\mathrm{SO}_{2}\end{array}$ & $\begin{array}{l}7.427 \\
41.9 \mathrm{mmHg} \\
98.2 \mathrm{mmHg} \\
27.1 \mathrm{mmol} / \mathrm{l} \\
+3.0 \mathrm{mmol} / \mathrm{l} \\
97.8 \%\end{array}$ \\
\hline $\begin{array}{l}\text { Renal function } \\
\text { Creatinine clearance } \\
\text { Potassium clearance } \\
\text { PSP test } \\
\text { Fishberg's concentration test }\end{array}$ & $\begin{array}{l}104 \mathrm{ml} / \mathrm{min} \\
15.9 \mathrm{ml} / \mathrm{min}(12-25) \\
49 \% / 15 \mathrm{~min} \\
104 \% / 120 \mathrm{~min} \\
1022 \sim 1029\end{array}$ \\
\hline Salivary sodium/potassium & $0.85(1-2)$ \\
\hline $\begin{array}{l}\text { Hormone levels in plasma or serum } \\
\text { Renin } \\
\text { Angiotensin II } \\
\text { Aldosterone } \\
\text { ACTH } \\
\text { DOC } \\
\text { Corticosterone } \\
\text { Cortisol } \\
\text { DHEA-S } \\
\text { ANP } \\
\text { Oestradiol } \\
\text { Progesterone } \\
\text { Testosterone }\end{array}$ & $\begin{array}{l}<5 \mathrm{pg} / \mathrm{ml}(2.5-21.4) \\
<0.4 \mathrm{pg} / \mathrm{ml}(<20) \\
<25 \mathrm{pg} / \mathrm{ml}(30-160) \\
35 \mathrm{pg} / \mathrm{ml}(6.1-55) \\
0.07 \mathrm{ng} / \mathrm{ml}(0.03-0.33) \\
1.43 \mathrm{ng} / \mathrm{ml}(0.21-8.48) \\
8.2 \mu \mathrm{gg} / \mathrm{dl}(4.4-17.4) \\
2590 \mathrm{ng} / \mathrm{ml}(400-3500) \\
27 \mathrm{pg} / \mathrm{ml}(<43) \\
99 \mathrm{pg} / \mathrm{ml}(10.0-321.8) \\
0.7 \mathrm{ng} / \mathrm{ml}(0.04-1.7) \\
<0.2 \mathrm{ng} / \mathrm{ml}(0.1-0.9)\end{array}$ \\
\hline $\begin{array}{l}\text { Hormone levels in urine } \\
17-\mathrm{KS} \\
17-\mathrm{OHCS} \\
\text { Free cortisol } \\
\text { Aldosterone } \\
\text { Adrenaline } \\
\text { Noradrenaline } \\
\text { Dopamine } \\
\text { Metanephrine } \\
\text { Normetanephrine } \\
\text { Kallikrein }\end{array}$ & $\begin{array}{l}7.8 \sim 12.3 \mathrm{mg} / \text { day }(3.3-13.8) \\
7.1 \sim 11.2 \mathrm{mg} / \mathrm{day}(2.4-5.8) \\
110 \sim 140 \mu \mathrm{g} / \mathrm{day}(31-99) \\
<1.0 \mu \mathrm{g} / \mathrm{day}(3-15) \\
8 \mu \mathrm{g} / \mathrm{day}(2-31) \\
93 \mu \mathrm{g} / \mathrm{day}(29-151) \\
1143 \mu \mathrm{g} / \mathrm{day}(282-1002) \\
0.09 \mathrm{mg} / \mathrm{day}(0.04-0.18) \\
0.16 \mathrm{mg} / \mathrm{day}(0.10-0.28) \\
0.7 \mathrm{U} / \mathrm{l}(0.3-7.9)\end{array}$ \\
\hline
\end{tabular}

Values within parentheses are normal ranges. BE, base excess; PSP, phenolsulphonphtalein; ACTH, adrenocorticotropin; DOC, II-deoxycorticosterone; DHEA-S, dehydroepiandrosterone sulphate; ANP, atrial natriuretic peptide; 17-KS, 17-ketosteroids; 17-OHCS, 17-hydroxycorticosteroids. 
gas analysis showed mild metabolic alkalosis. Renal function was normal.

\section{Case 2}

A 44-year-old Japanese female, the mother of patient 1 , was referred for further investigation of hypertension in October 1994, because her daughter was diagnosed as having Liddle's disease. She had developed hypertension at the age of 15 . Her height was $162 \mathrm{~cm}$, weight $75 \mathrm{~kg}$ and blood pressure 178/110 $\mathrm{mmHg}$. Her ocular fundus was normal and no left ventricular hypertrophy was found on electrocardiography or ultrasonic cardiography. The laboratory examination showed normal renal function, low to normal levels of potassium $(3.6 \mathrm{mEq} / \mathrm{l})$ and normal plasma steroid hormones. However, metabolic alkalosis ( $\mathrm{pH} 7.447, \mathrm{PaCO}_{2} 42.3 \mathrm{mmHg}$, $\mathrm{PaO}_{2} 66.5 \mathrm{mmHg}, \mathrm{HCO}_{3} 29.4 \mathrm{mmol} / \mathrm{l}$, base excess + $5.2 \mathrm{mmol} / \mathrm{l})$, low plasma renin activity $(<2.5 \mathrm{ng} / \mathrm{ml}$ per h) and a low plasma aldosterone concentration $(<25 \mathrm{ng} / \mathrm{ml})$ were found.

The pedigree of this family is shown in Fig. 1. The maternal grandmother of the proband (II-4 in Fig. 1) had hypertension with hypokalemia, but there are no detailed data for her. The maternal kindred are suspected of having the inherited trait of Liddle's disease because the proband's father (III-8 in Fig. 1) had hypertension with normal levels of plasma renin activity, plasma aldosterone and serum potassium since the age of 40, suggesting essential hypertension.

\section{Hormonal analysis}

Venous blood samples were drawn from the proband and her mother after informed consent had been obtained according to the Helsinki guidelines. Serum and urinary electrolytes were measured by flame photometry, plasma or serum hormones and urinary aldosterone by RIA, and catecholamine by HPLC. Urinary excretion of steroid hormones was analyzed by Dr Cedric Shackleton (Children's Hospital Oakland Research Institute, Oakland, CA, USA) as follows: the urine was extracted by Sep-pak, dried, reconstituted in $0.1 \mathrm{~mol} / \mathrm{l}$ acetate buffer and hydrolyzed. The resulting free steroids were extracted and taken up in methanol. Samples were analyzed on a Hewlett-Packard 5970 instrument by single-ion-monitoring (17).

\section{Single-strand conformation polymorphism (SSCP) and DNA sequence analysis}

SSCP and DNA sequence analysis were performed by Dr R P Lifton and Dr Yin Lu (Howard Hughes Medical Institute, Yale University School of Medicine, New Haven, CT, USA) as follows: DNA samples were extracted from whole blood leukocytes of the proband and her mother. The final exons of the genes encoding the $\alpha, \beta$ and $\gamma$ subunits of the hENaC were screened for molecular variants by SSCP. Specific primers were used to a direct PCR with genomic DNA. The PCR products were denatured and fractionated at room temperature by electrophoresis under non-denaturing conditions on polyacrylamide gels or MDE gels (AT Biochem, Malvern, PA, USA). After autoradiography of the gels, SSCP variants were identified, excised from the gel, and eluted. The products were then reamplified by PCR and subjected to direct DNA sequence analysis using an ABI 373 automated DNA sequencer employing either dye terminators or dye-labeled primers, following a standard protocol. DNA sequences were confirmed by sequencing both the DNA strands as described previously $(6,9,10$, 14-16).

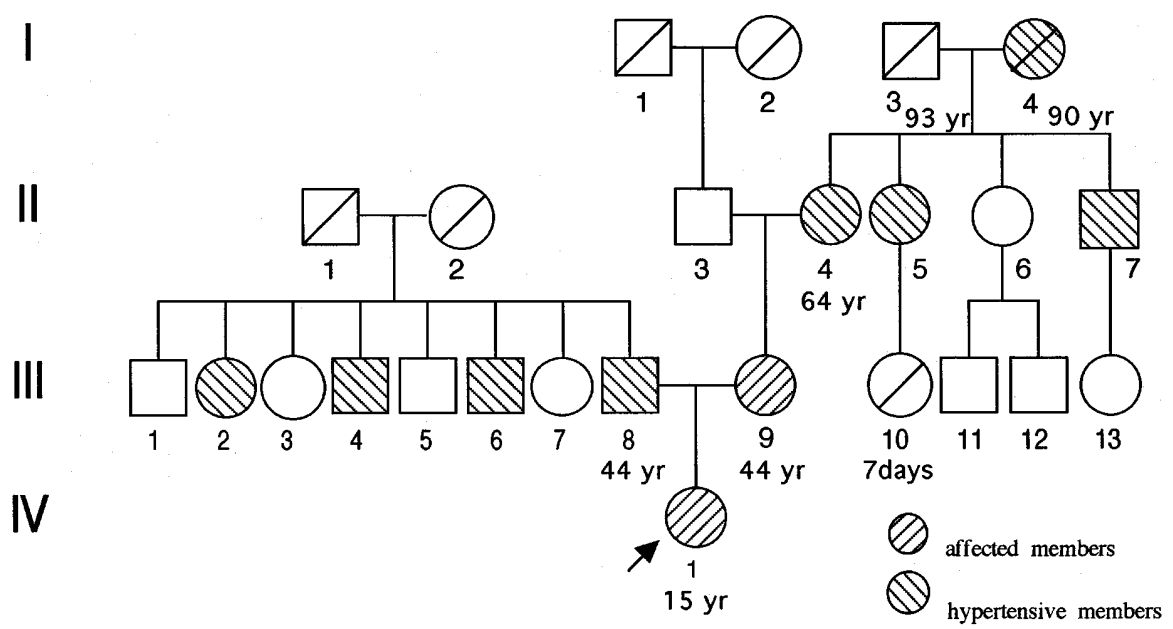

Figure 1 Pedigree of the present family with Liddle's disease. Squares indicate males and circles females. Kindred of the maternal line are strongly suspected of having the inherited trait of Liddle's disease. 


\section{Results}

Although serum cortisol and adrenocorticotropic hormone levels of the proband were normal, plasma renin and aldosterone concentrations were very low. Urinary excretion of 17-hydroxycorticosteroids and free cortisol was increased slightly (Table 1). The results of various loading tests carried out over 7 days are shown in Table 2 . In response to tetracosactide acetate $(250 \mu \mathrm{g}$, i.v.), serum 11-hydroxycorticosteroid and cortisol levels were elevated, but plasma aldosterone levels did not change. No plasma renin and aldosterone responses to furosemide administration (40 mg, i.v.) plus upright posture were observed. Blood pressure after spironolactone loading ( $400 \mathrm{mg} /$ day, per os) was decreased and serum potassium was increased slightly, but plasma renin and aldosterone levels showed no change. Dexamethasone administration ( $2 \mathrm{mg} /$ day, per os) elevated the proband's blood pressure but had no effects on serum potassium or plasma renin and aldosterone levels. In response to triamterene administration (150 mg/day, per os), blood pressure was lowered from $158 / 62 \mathrm{mmHg}$ to $144 / 80 \mathrm{mmHg}$ and serum potassium increased from 3.3 to $4.2 \mathrm{mEq} / \mathrm{l}$; however, plasma renin and aldosterone levels did not change. These results indicate that the renin-angiotensinaldosterone system of the proband was severely suppressed, spironolactone being slightly effective against the hypokalemic hypertension, and triamterene being the most effective.

Table 3 shows the urinary steroid hormone profile of the proband. Urinary cortisol was normal. Urine levels of other 3-oxo-4-ene-cortisol metabolites (6 $\beta$ hydroxycortisol, 20 $\alpha$-dihydroxycortisol, 20 $\beta$-dihydroxycortisol and 18-hydroxycortisol) were in the slightly low to normal range. The ratio of tetrahydrocortisol (THF) plus $5 \alpha$-THF (alloTHF) to tetrahydrocortisone (THE) was normal (0.63; normal range 0.5-2), in contrast with that in patients with AME Type I which was reported to be approximately 10-fold higher than normal (17). Moreover, the proband's level of tetrahydroaldosterone, a major aldosterone metabolite, was very low, strongly indicating suppressed excretion of aldosterone. Some of the above data suggested a diagnosis of Liddle's disease rather than AME sydrome. The proband was treated by dietary salt restriction and triamterene $(150 \mathrm{mg} /$ day, per os) medication, resulting in improvement of the hypertension and hypokalemia.

An SSCP variant was identified in the last exon of only the $\beta \mathrm{hENaC}$ in both the proband and her mother. Direct sequence analysis of the variant demonstrated a single cytosine base insertion mutation at Arg-597 in the cytoplasmic C-terminus of the $\beta \mathrm{hENaC}$ in both patients, as shown in Fig. 2A. This frameshift mutation altered the encoded protein from codon 598, and introduced a

Table 2 Results of various loading tests.

\begin{tabular}{|c|c|c|c|c|}
\hline \multicolumn{5}{|c|}{ 1. Rapid ACTH test (tetracosactide acetate $250 \mu \mathrm{g}$, i.v.) } \\
\hline $\begin{array}{l}11-\mathrm{OHCS}(\mu \mathrm{g} / \mathrm{dl}) \\
\text { Cortisol }(\mu \mathrm{g} / \mathrm{dl}) \\
\text { Aldosterone }(\mathrm{pg} / \mathrm{ml})\end{array}$ & $\begin{array}{l}\text { Basal } \\
19.0 \\
13 \\
<25\end{array}$ & $\begin{array}{l}30 \min \\
40.5 \\
23 \\
<25\end{array}$ & $\begin{array}{l}60 \min \\
35.9 \\
24 \\
<25\end{array}$ & $\begin{array}{l}\text { Normal range } \\
8-18 \\
4.4-17.4 \\
30-160\end{array}$ \\
\hline \multicolumn{5}{|c|}{ 2. Furosemide ( $40 \mathrm{mg}$, i.v.) plus upright posture test } \\
\hline $\begin{array}{l}\text { Renin }(\mathrm{pg} / \mathrm{ml}) \\
\text { Aldosterone (pg/ml) }\end{array}$ & $\begin{array}{l}\text { Basal } \\
<5 \\
<25\end{array}$ & $\begin{array}{l}60 \min \\
<5 \\
<25\end{array}$ & $\begin{array}{l}120 \min \\
<5 \\
<25\end{array}$ & $\begin{array}{l}\text { Normal range } \\
2.5-21.4 \\
30-160\end{array}$ \\
\hline \multicolumn{5}{|c|}{ 3. Spironolactone test ( $400 \mathrm{mg} / \mathrm{day}$, per os) } \\
\hline $\begin{array}{l}\text { Blood pressure }(\mathrm{mm} \mathrm{Hg}) \\
\text { Potassium }(\mathrm{mEq} / \mathrm{l}) \\
\text { Renin }(\mathrm{pg} / \mathrm{ml}) \\
\text { Aldosterone }(\mathrm{pg} / \mathrm{ml})\end{array}$ & $\begin{array}{l}\text { Day } 0 \\
152 / 80 \\
3.4 \\
<5 \\
30\end{array}$ & $\begin{array}{l}\text { Day } 4 \\
136 / 90 \\
3.6 \\
<5 \\
<25\end{array}$ & $\begin{array}{l}\text { Day } 7 \\
144 / 84 \\
3.7 \\
<5 \\
36\end{array}$ & $\begin{array}{l}\text { Normal range } \\
\\
3.6-5.0 \\
2.5-21.4 \\
30-160\end{array}$ \\
\hline \multicolumn{5}{|c|}{ 4. Dexamethasone test (2 mg/day, per os) } \\
\hline $\begin{array}{l}\text { Blood pressure }(\mathrm{mmHg}) \\
\text { Potassium }(\mathrm{mEq} / \mathrm{l}) \\
\text { Renin }(\mathrm{pg} / \mathrm{ml}) \\
\text { Aldosterone }(\mathrm{pg} / \mathrm{ml})\end{array}$ & $\begin{array}{l}\text { Day } 0 \\
134 / 94 \\
2.8 \\
<5 \\
34\end{array}$ & $\begin{array}{l}\text { Day } 4 \\
138 / 78 \\
2.8 \\
<5 \\
<25\end{array}$ & $\begin{array}{l}\text { Day } 7 \\
160 / 98 \\
3.0 \\
<5 \\
<25\end{array}$ & $\begin{array}{l}\text { Normal range } \\
3.6-5.0 \\
2.5-21.4 \\
30-160\end{array}$ \\
\hline \multicolumn{5}{|c|}{ 5. Triamterene test ( $150 \mathrm{mg} /$ day, per os) } \\
\hline $\begin{array}{l}\text { Blood pressure }(\mathrm{mmHg}) \\
\text { Potassium }(\mathrm{mEq} / \mathrm{l}) \\
\text { Renin }(\mathrm{pg} / \mathrm{ml}) \\
\text { Aldosterone }(\mathrm{pg} / \mathrm{ml})\end{array}$ & $\begin{array}{l}\text { Day } 0 \\
158 / 62 \\
3.3 \\
<5 \\
30\end{array}$ & $\begin{array}{l}\text { Day } 4 \\
150 / 74 \\
3.9 \\
<5 \\
<25\end{array}$ & $\begin{array}{l}\text { Day } 7 \\
144 / 80 \\
4.2 \\
<5 \\
<25\end{array}$ & $\begin{array}{l}\text { Normal range } \\
3.5-5.0 \\
2.5-21.4 \\
30-160\end{array}$ \\
\hline
\end{tabular}

ACTH, adrenocorticotropin; 11-OHCS, 11-hydroxycorticosteroid. 
Table 3 Urinary steroid hormone profile $(\mu \mathrm{g} / 24 \mathrm{~h})$ of the proband.

\begin{tabular}{|c|c|c|c|c|c|}
\hline \multicolumn{3}{|l|}{ Cortisol metabolites } & \multicolumn{3}{|l|}{ Mineralocorticoid metabolites } \\
\hline Cortisol & 55 & $(19-212)$ & Tetrahydroaldosterone & $<5$ & $(7-51)$ \\
\hline $6 \beta$-Hydroxycortisol & 62.42 & $(101-532)$ & Tetrahydro deoxycorticosterone & 5.817 & $(1-108)$ \\
\hline $20 \alpha$-Dihydrocortisol & 32.22 & $(22-92)$ & 18-Hydroxytetrahydro deoxycorticosterone & 16.94 & $(5-71)$ \\
\hline $20 \beta$-Dihydrocortisol & 46.02 & $(60-145)$ & & & \\
\hline 18-Hydroxycortisol & 130.1 & $(6-153)$ & Corticosterone metabolites & & \\
\hline$\alpha$-Cortol & 224.5 & $(67-287)$ & Tetrahydrocorticosterone & 56.20 & $(36-276)$ \\
\hline$\beta$-Cortol & 517.8 & $(37-759)$ & $5 \alpha$-Tetrahydrocorticosterone & 173.3 & $(79-525)$ \\
\hline Tetrahydrocortisol (THF) & 610.6 & $(312-1908)$ & & & \\
\hline $5 \alpha$-Tetrahydrocortisol (alloTHF) & 685.7 & $(164-1252)$ & 11-Deoxycortisol metabolites & & \\
\hline Tetrahydrocortisone (THE) & 2067 & $(639-3528)$ & Tetrahydrosubstance S & 42.88 & $(18-72)$ \\
\hline
\end{tabular}

Values within parentheses are normal ranges.

new stop codon at position 607 , thereby deleting the last 34 amino acids from the normally encoded protein (Fig. 2B).

\section{Discussion}

The present proband underwent extensive investigations into the cause of juvenile hypertension associated with hypokalemia, markedly suppressed plasma renin and aldosterone levels. As differential diagnoses, $11 \beta$ hydroxylase deficiency, $17 \alpha$-hydroxylase deficiency, deoxycorticosterone-producing tumor, corticosteroneproducing tumor, pheochromocytoma, renal arterial sclerosis, and Cushing's syndrome were easily excluded by the absence of virilization or hypogonadism and by laboratory data including steroid hormone profiles in blood and urine. However, AME syndrome is very difficult to exclude, because it is an autosomal recessive disorder in which the clinical findings closely resemble those of Liddle's disease; it is characterized by lowrenin hypertension and hypokalemic metabolic alkalosis despite subnormal levels of all known mineralocorticoids. AME syndrome can be classified on the basis of whether it has a congenital or acquired absence of $11 \beta$ hydroxysteroid dehydrogenase which mediates the conversion of cortisol to cortisone in the kidney (18, 19). The congenital syndrome has been further subdivided into type I and II; AME type I, the classical

(A) GCCCCCCCG
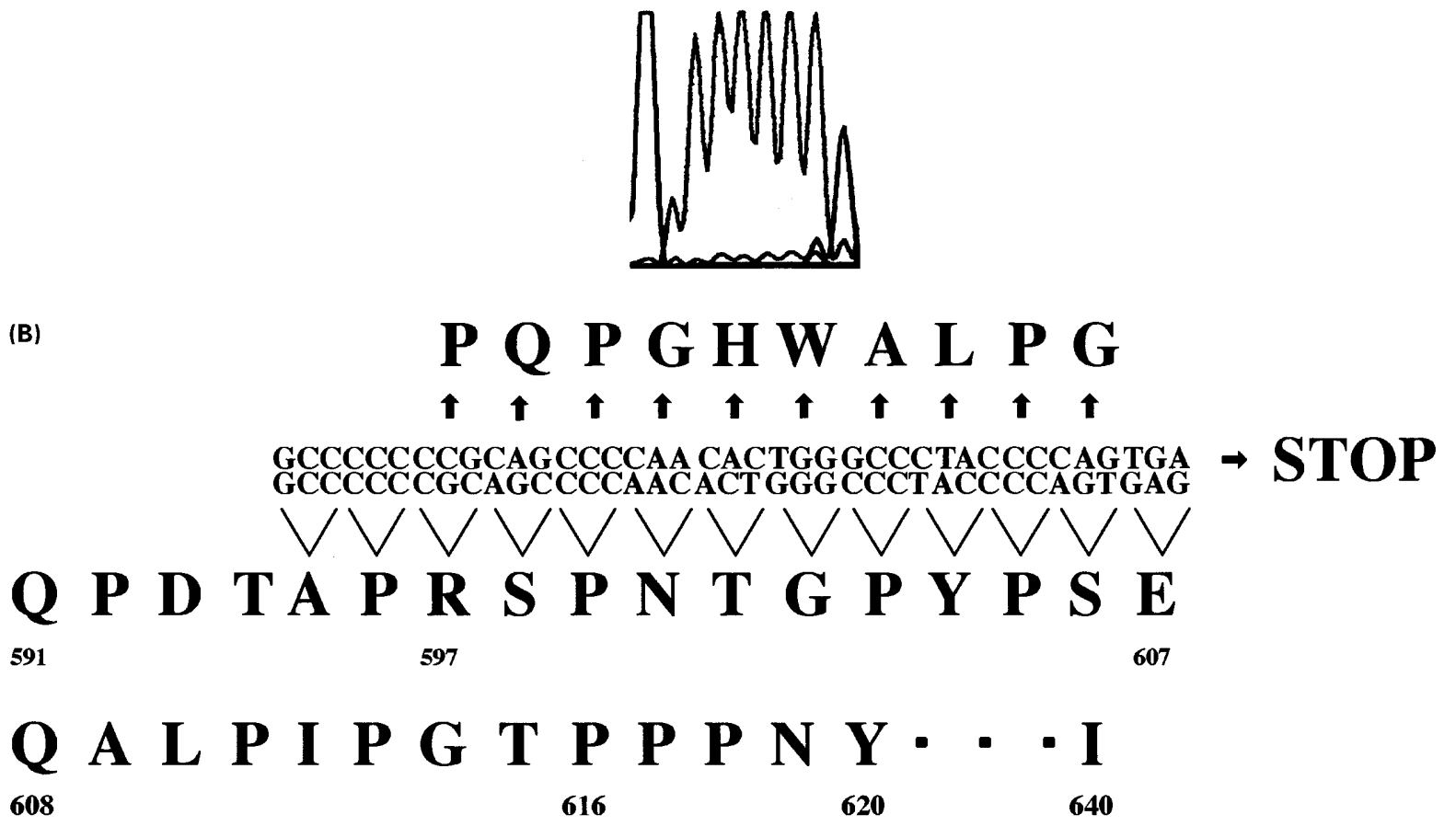

Figure 2 (A) DNA sequence of the identified mutation. A single cytosine insertion mutation at codon 597 is shown. The $5^{\prime}$ to $3^{\prime}$ orientation of the sequence is left to right. (B) The Arg-597 (CGC) to Pro (CCG) mutation introduces a new stop codon at Glu-607 because of a frameshift, thereby deleting the last 34 amino acids including the PY motif at codons 616 to 620 . 
type, usually responds to spironolactone administration with a low-sodium diet, and the ratio of THF plus alloTHF to THE was demonstrated to be high, whereas AME type II exhibits a normal ratio of urinary cortisol to cortisone metabolites because the pathogenesis may be a defect in A ring reduction, resulting in impaired deactivation of biologically active cortisol in target tissue cells $(19,20)$. In the present proband, the effect of spironolactone on her blood pressure and the high levels of 17-hydroxycorticosteroids and free cortisol in the urine suggested AME syndrome, but the normal THF plus alloTHF to THE ratio in the comprehensive urinary steroid hormone analysis indicated that she did not have an AME type of disorder. Moreover, we could finally distinguish Liddle's disease from AME type II by the lack of a beneficial effect of dexamethasone on blood pressure and hypokalemia. Mune et al. (21) recently analyzed the gene encoding the renal isozyme of $11 \beta$ hydroxysteroid dehydrogenase and demonstrated inactivating mutations on both alleles in 9 of 11 patients with AME.

Nine mutations, consisting of eight in the $\beta$ hENaC including the present family and one in the $\gamma \mathrm{hENaC}$, have been reported $(14,15,22-25)$; the genetic variants are composed of six nonsense mutations including three stop codons, two insertions and one deletion, and three missense mutations. Although the nonsense mutations are widely positioned at codons 566 to 597 truncating the last 34-75 amino acids of the $\mathrm{C}$-terminus, the missense mutations are narrowly positioned at codons 617,618 and 620 . The mutation of the present kindred resembles that (K176) reported by Shimkets et al. $(14,24)$; K176 has the insertion of a single cytosine residue introducing a frameshift mutation into the encoding protein at Thr-594, resulting in a new stop codon at Glu-607, as does the present kindred. However, the amino acids of the C-terminus in our kindred are longer than those in K176 by three, indicating that the present mutation retains the longest C-terminal portion of the wild-type subunit compared with the previously described nonsense and frameshift mutations $(14,15,22-25)$. Mutations of the PPPXY sequence (PY motif) of the C-terminus of the $\beta$ hENaC have been reported in three kindreds to date. Hansson et al. (16) recently reported a Liddle's kindred with a missense mutation at Pro-618 (Leu (CTC) instead of Pro $(\mathrm{CCC})$ ), and demonstrated that this single amino acid substitution resulted in an 8.8-fold increase in sodium channel activity; they concluded that a proline-rich segment is critical for the regulation of channel activity. Tamura et al. (22) reported on a family affected with Liddle's disease with a missense mutation of Tyr-620 (TAT) to His (CAT), and demonstrated that increased $\mathrm{ENaC}$ activity was functionally equivalent to the mutation at Arg-566 identified in the original Liddle's kindred. Finally, Inoue et al. (23) described the missense mutation of Pro-617 (CCC) to Ser (TCC) in four affected members of a Liddle's kindred.
Two groups of investigators have recently demonstrated that the deletion or substitution of the PY motif of the $\beta$ and $\gamma \mathrm{ENaC}$ led to a marked increase in sodium transport, suggesting that the PY motif plays an important part in the down-regulation mechanism of channel activity $(7,8)$. Snyder et al. (7) have shown an increase in cell surface expression of the $\mathrm{ENaC}$; they speculated that the observed increase in sodium channel activity in the PY motif mutants may be caused by a defect in the degradation of the channel subunits. Staub et al. (8) identified the rat homolog of Nedd 4 as the binding partner for the protein-rich sequence at the $\mathrm{C}$-terminus of rat $\mathrm{ENaC}$ using a yeast two-hybrid system. Rat Nedd 4 contains a $\mathrm{Ca}^{2+}$ lipidbinding domain, three WW domains and a ubiquitin ligase domain; it functions in the protein degradation process of the cell membrane. It is possible that the three WW domains of Nedd 4 bind the PY motif in the Cterminus of the $\mathrm{ENaC}$ and that the ubiquitin ligase domain initiates the degradation of the channel. A defective or missing PY motif would result in increased numbers of sodium channels on the cell surface, thereby increasing sodium reabsorption and leading to the Liddle's phenotype.

The proband and her kindred reported first by Liddle et al. and genetically analyzed by Shimkets et al. had severe hypertension $(1,4,14)$, but all members of the present kindred had mild hypertension and long-term survival without severe complications (Fig. 1). Thus Liddle's disease seems to be a clinically and genetically heterogeneous disorder (14-19, 24). Elucidation of this heterogeneity would appear to be important for affected kindreds at risk, and the detailed mechanism remains to be identified. In the present patients, the normal PY motif in the cytoplasmic C-terminus of the $\beta$ subunit was completely missing (Fig. 2); nevertheless, their clinical data did not indicate severe hypertension compared with Liddle's original cases, suggesting that the interaction between the PY motif and Nedd 4 is not the only etiology of Liddle's disease. In addition, the amino acid loss in our patients was about half of that in Liddle's original kindred; this result strongly suggests that the length of the C-terminus of the $\beta \mathrm{hENaC}$ may be related to the clinical severity of the disease, if the PY motif is missing. As Schild et al. noted (9), the relationship between the size of the deleted fragment and the increase in $\mathrm{ENaC}$ activity suggests that the length of the C-terminus is one factor determining the importance of the functional alteration of $\mathrm{ENaC}$ activity.

In summary, we have demonstrated that a novel cytosine insertion mutation in the final exon of the $\beta$ $\mathrm{hENaC}$ is responsible for Liddle's disease in this Japanese family. Further genetic work is required to clarify the pathogenesis of this rare disorder and the pathophysiological roles of the $\mathrm{hENaC}$ in the distal nephron. 


\section{Acknowledgements}

The authors are grateful to Dr R P Lifton and Dr Yin Lu, Howard Hughes Medical Institute, Yale University School of Medicine, New Haven, Connecticut, USA for the determination of SSCP and DNA sequence analysis, to Dr C H L Shackleton, Children's Hospital Oakland Research Institute, Oakland, California, USA for the determination of total urine steroids, and to Dr Hiroshi Suzuki, First Department of Internal Medicine, Hyogo College of Medicine, Hyogo, Japan for his advice.

\section{References}

1 Liddle GW, Bledsoe T \& Coppage Jr WS. A familial renal disorder simulating primary aldosteronism but with negligible aldosterone secretion. Transactions of the Association of American Physicians 196376 199-213.

2 Lifton RP. Genetic determinants of human hypertension. Proceedings of the National Academy of Sciences of the USA $1995928545-$ 8551 .

3 Warnock DG \& Bubien JK. Liddle syndrome: clinical and cellular abnormalities. Hospital Practice 199429 95-105.

4 Botero-Velez M, Curtis JJ \& Warnock DG. Brief report: Liddle's syndrome revisited: a disorder of sodium reabsorption in the dista tubule. New England Journal of Medicine 1994330 178-181.

5 Warnock DG \& Bubien JK. Liddle's syndrome: a public health menace? American Journal of Kidney Disease 199525 924-927.

6 Schild L, Canessa CM, Shimkets RA, Gautschi I, Lifton RP \& Rossier BC. A mutation in the epithelial sodium channel causing Liddle disease increases channel activity in the Xenopus laevis oocyte expression system. Proceedings of the National Academy of Sciences of the USA 199592 5699-5703.

7 Snyder PM, Price MP, McDonald FJ, Adams CM, Volk KA, Zeiher BG et al. Mechanism by which Liddle's syndrome mutations increase activity of a human epithelial $\mathrm{Na}^{+}$channel. Cell 199583 969-978.

8 Staub O, Dho S, Henry PC, Correa J, Ishikawa T, McGlade J et al. WW domains of Nedd 4 bind to the proline-rich PY motifs in the epithelial $\mathrm{Na}^{+}$channel deleted in Liddle's syndrome. EMBO Journal 199615 2371-2380.

9 Schild L, Lu Y, Gautschi I, Schneeberger E, Lifton RP \& Rossier BC. Identification of a PY motif in the epithelial $\mathrm{Na}$ channe subunits as a target sequence for mutations causing channel activation found in Liddle syndrome. EMBO Journal 199615 2381-2387.

10 Canessa CM, Schild L, Buell G, Thorens B, Gautschi I, Horisberger JD et al. Amiloride-sensitive epithelial $\mathrm{Na}^{+}$channel is made of three homologous subunits. Nature 1994367 463-467.

11 Chang SS, Grunder S, Hanukoglu A, Rösler A, Mathew PM, Hanukoglu I et al. Mutations in subunits of the epithelial sodium channel cause salt wasting with hyperkalaemic acidosis, pseudohypoaldosteronism type 1. Nature Genetics 199612 248-253.
12 Hummler E, Barker P, Gatzy J, Beermann F, Verdumo C, Schmidt A et al. Early death due to defective neonatal lung liquid clearance in $\alpha$ ENaC-deficient mice. Nature Genetics 199612 325-328.

13 McDonald FJ, Price MP, Snyder PM \& Welsh MJ. Cloning and expression of the $\beta$ - and $\gamma$-subunits of the human epithelial sodium channel. American Journal of Physiology 1995268 C1157-C1163.

14 Shimkets RA, Warnock DG, Bositis CM, Nelson-Williams C, Hansson JH, Schambelan M et al. Liddle's syndrome: heritable human hypertension caused by mutations in the $\beta$ subunit of the epithelial sodium channel. Cell 199479 407-414.

15 Hansson JH, Nelson-Williams C, Suzuki H, Schild L, Shimkets R, $\mathrm{Lu} \mathrm{Y}$ et al. Hypertension caused by a truncated epithelial sodium channel $\gamma$ subunit: genetic heterogeneity of Liddle syndrome. Nature Genetics $19951176-82$.

16 Hansson JH, Schild L, Lu Y, Wilson TA, Gautschi I, Shimkets R et al. A de novo missense mutation of the $\beta$ subunit of the epithelial sodium channel causes hypertension and Liddle syndrome, identifying a proline-rich segment critical for regulation of channel activity. Proceedings of the National Academy of Sciences of the USA 199592 11495-11499.

17 Shackleton CHL. Mass spectrometry in the diagnosis of steroidrelated disorders and in hypertension research. Journal of Steroid Biochemistry and Molecular Biology 199345 127-140.

18 New MI, Levine LS, Biglieri EG, Pareira J \& Ulick S. Evidence for an unidentified steroid in a child with apparent mineralocorticoid hypertension. Journal of Clinical Endocrinology and Metabolism $197744924-933$.

19 Edwards CRW, Walker BR, Benediktsson R \& Seckl JR. Congenital and acquired syndromes of apparent mineralocorticoid excess. Journal of Steroid Biochemistry and Molecular Biology 199345 1-5.

20 Mantero F, Tedde R, Opocher G, Fulgheri PD, Arnaldi G \& Ulick S. Apparent mineralocorticoid excess type II. Steroids 199459 80-83.

21 Mune, T, Rogerson FM, Nikkilä H, Agarwal AK \& White PC. Human hypertension caused by mutations in the kidney isozyme of $11 \beta$-hydroxysteroid dehydrogenase. Nature Genetics 199510 394-399.

22 Tamura H, Schild L, Enomoto N, Matsui N, Marumo F, Rossier BC et al. Liddle disease caused by a missense mutation of $\beta$ subunit of the epithelial sodium channel gene. Journal of Clinical Investigation $1996971780-1784$.

23 Inoue J, Yamaguchi K, Iwaoka T, Naomi S, Tokunaga H, Disashi T et al. A family with Liddle's syndrome caused by a new missense mutation in the $\beta$ subunit of the epithelial sodium channel. Hypertension Research 199619305.

24 Findling JW, Raff H, Hansson JH \& Lifton RP. Liddle's syndrome: prospective genetic screening and suppressed aldosterone secretion in an extended kindred. Journal of Clinical Endorinology and Metabolism 199782 1071-1074.

25 Inoue T, Okauchi Y, Yokogoshi Y, Shintani Y, Bando H \& Saito S. Liddle's disease caused by a novel insertion mutation. Hormone to Rinsho 199745 (suppl) 230-234 (in Japanese).

Received 21 November 1997

Accepted 17 February 1998 